\title{
Gesture in Visual Narrative Reliefs of Karmawibhangga Borobudur as An Ancient Javanese Locality Value
}

\author{
Hendy Hertiasa $^{1, *}$ Imam Santosa $^{2}$, Irfansyah Irfansyah ${ }^{3,}$ Pindi Setiawan ${ }^{4}$
}

\author{
${ }^{1}$ Institut Teknologi Bandung \\ ${ }^{2}$ Institut Teknologi Bandung \\ ${ }^{3}$ Institut Teknologi Bandung \\ ${ }^{4}$ Institut Teknologi Bandung \\ ${ }^{*}$ Corresponding author. Email: pixelhendy@gmail.com
}

\begin{abstract}
The relief of Karmawibhangga tells the form of a series of short stories in a full circle embedded at the foot of the underground Borobudur temple, Central Java - Indonesia. Currently, the visual reliefs story cannot be understood properly by visitors. It is known that the main character becomes the centre of attention for the audience or reader in a story. The ability to read and interpret the story of relief, especially the main characters is very useful for visitors to build a higher quality experience and knowledge in the edutainment media of the Borobudur heritage destination. However the interpretation of characters gestures in the visual reliefs is unknown. This study focuses on the main character's gestures with visual narrative text structure approach, about the form of the story or content that is constructed by events and existence. The visual language method is useful to analyse what and how the visual relief gestures are depicted. Then the nawarasa aesthetic is used as a method for classifying nine meaning of gesture, which reveal actions both physically and mentally. The aesthetic concept of nawarasa has undergone a creative transformation into a unique ancient Javanese aesthetic form. As we can clearly see, the research findings show that most of the Karmawibhangga reliefs depict the daily life of the ancient Javanese people which is very distinctive with various social stratifications.
\end{abstract}

Keywords: Karmawibhangga Relief, Narrative Structure, Visual Language, Gestures, Navarasa.

\section{INTRODUCTION}

Relief is a visual engraving that usually gives a three-dimensional impression on a wood, metal, or stone surface. The reliefs of Borobudur temple are made of andesite stone which is a type of low relief (bas-relief) where the relief is used to complement the elements of the temple as a style form of ornamental or narrative. 160 of the 1460 narrative relief panels of Karmawibhangga reliefs that tell a series of short stories, where the main theme of the story contains a set of Buddhist didactic theories of karma (causation). Approximately 1241 years Karmawibhangga relief hidden at the foot of the temple [1]. In 1885 researchers led by I.W. Ijzerman found by accident a beautiful relief at the base of Borobudur. In 1890-1891 each relief panel was photographed by Kassian Cephas and then replanted [2]. Reliefs 021 and 022 were found and dismantled in 1943 by Yasujiro Furuzawa of the Japanese occupation army, 29 years later UNESCO dismantled part of the hallway in the southeast corner and reopened two reliefs 019,020 so that the total in the southeast corner is relief 019,020 , 021,022 [3]. Until now, visitors can only see four reliefs of Karmawibhangga in the southeast corner of the temple.

Karma, karman, kamma (Pāli), kôrmô (Bengali), pinyin (Chinese), rōmaji (Japanese), wylie (Tibetan), gam (Thai) are Sanskrit terms literally meaning "actions" or "deeds", which are by intention (cetanā), [3] carried out intentionally through body, speech or mind leading to future consequences, wherein individual intentions and actions (cause) affect the individual's future (effect). Karma (actions or deeds) wibhangga (waves or grooves), Karmawibhangga means the flow or waves of human life, both during 
life and after death. The Law of Karma or the Law of Cause and Effect stipulates that an action must have a consequence, karma applies to all people, whether kings, nobles, priests or the common people, [4] The reading of the stories of each relief panel by means of pradaksina is also associated with the way of holding religious ceremonies with a procession going around in a clockwise direction. The relief style has the following characteristics: naturalist, various flora and fauna, human characters with faces directed at the audience (enface), story themes and sources of relief stories using both Indian stories and local stories [5]. However, it is unfortunate that most visitors to Borobudur cannot read clearly the characters and actions of the protagonists and antagonists told in the reliefs, so they do not know the meaning of the components or forms of the relief stories of Indonesia's greatest heritage for the world.

Gesture is a form of non-verbal communication or non-vocal communication in which visible bodily actions communicate certain messages, either in lieu of, or in conjunction with, speech [6]. This study focuses on the main character's gestures that build the scene in the form of a story in the relief. The main objective of this research is to find the value of locality through gestures (characters and actions) in the visual relief of Karmawibhangga. Qualitative research was carried out using the Chatman narrative text structure approach, about the form of stories built by events and existents. To observe gestures carefully, a visual language approach is needed, especially in wimba and isi wimba. While the aesthetic classification of navarasa is used to look for the peculiarities of the gestures in the Karmawibhangga relief. Although the nawarasa aesthetic originates from ancient Indian culture which was brought to the island of Java as a standard pattern of Hindu-Buddhist iconographic expression, that has undergone a creative transformation into distinctive ancient Javanese aesthetic form. By carrying out the stages of the research process mentioned above, we will know and understand the sequence themes of story, various main character gestures, and the values of ancient Javanese locality contained in it.

\section{METHODS}

Interpretive descriptive qualitative research is carried out based on the focus of research, data collection, analysis process through depiction and interpretation of data, where all researcher abilities become the basis for interpretation to view the world and the knowledge and theoretical basis used. The structural approach in this study aims to build an objective picture of the form of the story and the main character's gestures that become the nodes for all narrative components in the relief. The research data is in the form of gestures of the main characters in a collection of 160 Karmawibhangga relief stories, both visually and textually, where textual literature data is collected from various sources to complete the visual relief narrative data that becomes a unified whole story, thus we can find out all the main character's gestures in the relief. The research carried out requires triangulation of data, methods and theories. The stages of research based on textual and visual literature were as follows: collecting documentation of 160 digital relief photos and textual literature; field survey and observation of four exposed reliefs that can be seen; combining narrative structure with visual language methods, and navarasa aesthetics to identify and analyze the form of the story (events and existents) to determine the main character's gestures for each relief; looking for similarities and compatibility of gestural expressions between the results of visual relief narrative text analysis with the classical aesthetic method of ancient Javanese navarasa, so that the similarity and conformity can be an indicator of locality value in the Karmawibhangga Borobudur relief.

\subsection{Narrative Structures}

Narrative structure according to Seymour Chatman [7] is divided into two, the first is story or content, and the second is discourse or expression. He also explained that linguistics and semiotics (the study of signs), explain the difference between "content and expression", between "substance and form". Narrative structure is also semiotic, communicates meaning by itself, contains form and substance of expression (discourse), and has form and substance of content (story). To explore the main character's gestures, we will focus on the form of the story, Where the form of the story or contents is shaped by events and existents, the sequence of events is shaped by actions and happenings, while existents is shaped by characters and settings, as depicted in the following figure 1.: 


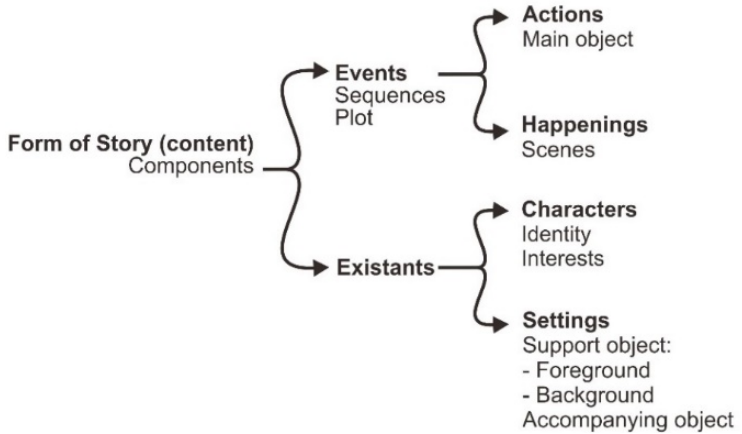

Figure 1. Adaptation from Chatman (1980): form of story

According to Chatman that actions or deeds, behavior, thoughts, traits, habits, emotions, desires, human instincts; a series of events (plot) or sequence is an event at a certain time and place; happenings (scenes) can be said as circumstances, phenomena, episodes; Settings puts characters in place and their properties, with criteria as settings, namely: Living object (support object and accompanying object), identity (nominations), interests. Identity (nomination) and interests as foreground and background objects, property. Thus, to know gestures in depth, we must analyze all forms of the story (content), namely: events or plot or sequence (actions and happenings/ scenes) and existents (characters and settings).

\subsection{Visual Language}

Visual Images that are able to transfer information and meaning of messages without writing. In the Classical Hindu-Buddhist era, it showed a high written culture, as well as an amazing artistic culture, as shown in the cultural heritage of
Borobudur temple. The visual language method according to Primadi Tabrani [8], aims to analyze what and how the reliefs are told, with wimba and isi wimba aim to determine the denotation of an attitude and action in the image of the main character. Wimba is a single image and isi wimba are the names of the images or those drawn, describing a scene or a combination of a number of interrelated wimba. He also emphasized that it takes two stages of comprehension in reading a picture of the main character, namely: comprehension stage 1 is the general rule of reading relief pictures; the number of acts and scenes in one complete picture, storytelling is a combination of a number of interrelated scenes. While the comprehension stage 2 is aimed at describing the smallest elements of one image or describing the whole in a single image.

\subsection{Navarasa Aesthetics}

In the Indian aesthetic conception "rasa" means "juice, essence or taste", regarding the aesthetic taste of any literary, visual, sculptural, musical work that evokes emotions or feelings in the reader or viewer [9]. The theory of taste was first formulated by a sage Bharatamuni on Ndtyahdstra in the 2nd century [10], the aesthetic theory of rasa then developed into Indonesia, but experiencing a distinctive regional creative evolution [11]. This can be seen in the ancient Javanese literary art of Chandakarana which was written under the orders of Sri Maharaja Jitendra of the 8th century Sailendra dynasty, giving influence to create a distinctive identity in architectural iconographic symbols and beautiful reliefs of Borobudur including Karmawibhangga [12], as shown in the table 1.

The classical idiom of Chandakarana's composition, is the treatise on 'the art of writing

Table 1. Adaptation from Nirmala Sharma (2008): gesture manifestation of navarasa in nine passion aesthetics

\begin{tabular}{|c|c|c|c|c|c|c|c|c|c|}
\hline & $\begin{array}{l}\text { The heroic } \\
\text { Vira Rasa }\end{array}$ & $\begin{array}{l}\text { Marvelous } \\
\text { Abhuta Rasa }\end{array}$ & $\begin{array}{l}\text { The erotic } \\
\text { Srngara Rasa }\end{array}$ & $\begin{array}{l}\text { The Comic } \\
\text { Hasya Rasa }\end{array}$ & $\begin{array}{l}\text { The peaceful } \\
\text { Santa Rasa }\end{array}$ & $\begin{array}{l}\text { The pathetic } \\
\text { Karuna Rasa }\end{array}$ & $\begin{array}{l}\text { The furious } \\
\text { Raudra Rasa }\end{array}$ & $\begin{array}{l}\text { Scary } \\
\text { Bhayanaka Rasa }\end{array}$ & $\begin{array}{l}\text { The odious } \\
\text { Bibatsa Rasa }\end{array}$ \\
\hline $\begin{array}{l}\text { External } \\
\text { Factors }\end{array}$ & $\begin{array}{l}\text { Injustice } \\
\text { Humanity } \\
\text { Struggle } \\
\text { Civilization }\end{array}$ & $\begin{array}{l}\text { Beautiful } \\
\text { Amazing } \\
\text { Patience } \\
\text { Strength }\end{array}$ & $\begin{array}{l}\text { Beauty } \\
\text { Erotic } \\
\text { Eros } \\
\text { Harmony }\end{array}$ & $\begin{array}{l}\text { joy } \\
\text { Joke } \\
\text { Funny } \\
\text { Sleep }\end{array}$ & $\begin{array}{l}\text { Peace } \\
\text { Spirituality } \\
\text { Paradise } \\
\text { Supernatural }\end{array}$ & $\begin{array}{l}\text { Berpisah } \\
\text { Kesusahan } \\
\text { Kehilangan } \\
\text { harapan }\end{array}$ & $\begin{array}{l}\text { Contradictions } \\
\text { Difference } \\
\text { Hostility }\end{array}$ & $\begin{array}{l}\text { Ignorance } \\
\text { Confusion } \\
\text { Darkness } \\
\text { Alienation }\end{array}$ & $\begin{array}{l}\text { Smell } \\
\text { Blood } \\
\text { Meat } \\
\text { Carcass }\end{array}$ \\
\hline $\begin{array}{l}\text { Internal } \\
\text { Factors }\end{array}$ & $\begin{array}{l}\text { Spirit } \\
\text { Enthusiastic } \\
\text { Generous } \\
\text { allied } \\
\text { Pride } \\
\text { Attention }\end{array}$ & $\begin{array}{l}\text { fascinated } \\
\text { shocked } \\
\text { Surprised } \\
\text { Amazed } \\
\text { Guessing }\end{array}$ & $\begin{array}{l}\text { Scent } \\
\text { Longing } \\
\text { wish } \\
\text { Physical } \\
\text { love }\end{array}$ & $\begin{array}{l}\text { Excitement } \\
\text { cheerful } \\
\text { Abandonment } \\
\text { Courtesy } \\
\text { Indecent }\end{array}$ & $\begin{array}{l}\text { Calm } \\
\text { Spiritual } \\
\text { Right } \\
\text { Generous } \\
\text { Virtue } \\
\text { Purity }\end{array}$ & $\begin{array}{l}\text { Emotion state } \\
\text { Temporary } \\
\text { Sentiment } \\
\text { Failure }\end{array}$ & $\begin{array}{l}\text { Offended } \\
\text { Wrath } \\
\text { antipathy } \\
\text { Emotion } \\
\text { Unconscious }\end{array}$ & $\begin{array}{l}\text { Terror } \\
\text { Afraid } \\
\text { Worry } \\
\text { Stressed }\end{array}$ & $\begin{array}{l}\text { Disgust } \\
\text { Fed up }\end{array}$ \\
\hline $\begin{array}{l}\text { Gesture } \\
\text { Expression }\end{array}$ & $\begin{array}{l}\text { Charity } \\
\text { Mercy } \\
\text { Struggle } \\
\text { Resistance } \\
\text { Bravery } \\
\text { Protect } \\
\text { Entertain } \\
\text { glorious }\end{array}$ & $\begin{array}{l}\text { Sweat } \\
\text { Shiver } \\
\text { Hoarseness } \\
\text { Confusion } \\
\text { Eyes wide } \\
\text { Confusion } \\
\text { wish }\end{array}$ & $\begin{array}{l}\text { Wise } \\
\text { Polite } \\
\text { Knitting } \\
\text { Eyebrows } \\
\text { Glancing } \\
\text { in love } \\
\text { Enjoyment } \\
\text { Favorite }\end{array}$ & $\begin{array}{l}\text { Laugh } \\
\text { Smile } \\
\text { Joking } \\
\text { Speech } \\
\text { distortion } \\
\text { Weird action }\end{array}$ & $\begin{array}{l}\text { hermitage } \\
\text { Holy place } \\
\text { River } \\
\text { Forest } \\
\text { Paradise } \\
\text { Ecstasy } \\
\text { Meditation } \\
\text { Restraint }\end{array}$ & $\begin{array}{l}\text { Cry } \\
\text { Gather } \\
\text { Asleep } \\
\text { Weak } \\
\text { Sad } \\
\text { Hopeless } \\
\text { Suffer } \\
\text { Sick }\end{array}$ & $\begin{array}{l}\text { Knitting } \\
\text { eyebrows } \\
\text { Biting lips } \\
\text { Punching } \\
\text { Hold up } \\
\text { weapon } \\
\text { Malignant } \\
\text { upset }\end{array}$ & $\begin{array}{l}\text { Hell } \\
\text { Perish } \\
\text { Ghost } \\
\text { Suspicion } \\
\text { Oppression } \\
\text { Unconscious } \\
\text { Chaos }\end{array}$ & $\begin{array}{l}\text { Gag } \\
\text { Turn away } \\
\text { Close eyes } \\
\text { Avoid }\end{array}$ \\
\hline
\end{tabular}


poetry', on rasa in nine categories, namely: Vira Rasa (Heroism), Adbhuta Rasa (The marvelous), Srngara Rasa (The erotic), Hasya Rasa (The comic), Karuna Rasa (The pathetic/ sorrowful), Raudra Rasa (The furious), Bhayanaka Rasa (The terrible), Bibhatsa Rasa (The odious), Santa Rasa (The peaceful). Nawarasa aesthetics are expressed as a result of the interaction of external factors and internal factors in the figure of a main character.

\subsection{Triangulation Data, Theory and Method}

Triangulation of data, theories and methods to build understanding, explore theoretical knowledge in depth. Triangulation as a combination of various data, theories and methods, is a process of collecting and analyzing data that is approached from various perspectives to obtain a complete picture of complex and deep symptoms, events, facts, reality, and meanings. In the study of the main character's gestures, triangulation methods are needed in tables 2 .

\section{RESULT AND DISCUSSION}

At this stage will be explained about: the model of reading the main character's gestures; classification of reading movements using the navarasa definition; examples of the main character's gestures in a distinctive and unique relief; An example reading the main character's gestures; at the same time will discuss the findings revealed and the implications of these findings.

\subsection{Model of Reading the Main Character's Gestures}

Before observing visual relief, by referring to Chatman and Tabrani, we must first understand the general provisions of visual relief language as follows: read in pradaksina way (from right to left); main character (main object) is fully depicted (from head to toe); the object of relief picture consists of: main object, accompanying object, supporting object; main object is the object that is the core of the scene; accompanying object: accompany the presence of the main object; supporting object consist of: foreground, background, ornament/symbolic; foreground: people flora, fauna, buildings, location markers; background: people, flora, fauna, buildings, location markers for the periodization of events; ornament/ symbol: natural sign, ritual medium; relief picture prioritizes gesture $\&$ posture.

In relation to the main character's gestures, it is necessary to describe: the form of the story, namely events (actions and happenings) and existents (characters and settings); wimba and isi wimba; then look for the type of navarasa gesture classification on the relief; as well as searching for the necessary literature to mark the identity and features of the relief is the final part of the analysis process. Thus, four stages of analysis of the main character's movements were carried out, as follows: (1) first stage, with pradaksina to observe the entire relief image which aims to determine the stages and limits of sequence so that we can determine the number of sequences (plot) in the relief. After determining the number of sequences, then we limit observations to parts of the scene according to the specified sequence. (2) Second stage, which is the main stage of the analysis process, is to find out the main characters by observing full

Table 2. Triangulation, the main character gestures Karmawibhangga

\begin{tabular}{|c|c|c|c|c|}
\hline $\begin{array}{l}\text { Narrative Text Structure: } \\
\text { Story (content) Form } \\
\text { Seymour Chatman (1978) }\end{array}$ & & $\begin{array}{l}\text { Visual Language } \\
\text { Primadi Tabrani } \\
\text { (1991) }\end{array}$ & $\begin{array}{l}\text { Navarasa } \\
\text { Reperesentation of Rasa on } \\
\text { The Hidden Base of The Borobudur } \\
\text { Nirmala Sharma (2018) }\end{array}$ & $\begin{array}{l}\text { Main Character } \\
\text { Gesture } \\
\text { Karmawibhangga }\end{array}$ \\
\hline $\begin{array}{l}\text { Form of Story (content) } \\
\text { Components }\end{array}$ & $\begin{array}{l}\text { Actions } \\
\text { Main object } \\
\text { Happenings } \\
\text { Scenes } \\
\text { Characters } \\
\text { Identity } \\
\text { Interests } \\
\text { Settings } \\
\text { Support object: } \\
\text { - Foreground } \\
\text { - Background } \\
\text { Accompanying object }\end{array}$ & $\begin{array}{l}\text { Wimba } \\
\text { Sub Imaji } \\
\text { Imaji } \\
\text { Isi Wimba } \\
\text { Atmosphere } \\
\text { Scene }\end{array}$ & $\begin{array}{l}\text { Vira Rasa } \\
\text { (Heroism) } \\
\text { Adbhuta Rasa } \\
\text { (The marvelous) } \\
\text { Srgara Rasa } \\
\text { (The erotic) } \\
\text { Hasya Rasa } \\
\text { (The comic) } \\
\text { Karuna Rasa } \\
\text { (The pathetic) } \\
\text { Raudra Rasa } \\
\text { (The furious) } \\
\text { Bhayanaka Rasa } \\
\text { (The terrible) } \\
\text { Bibhatsa Rasa } \\
\text { (The odious) } \\
\text { Santa Rasa } \\
\text { (The peaceful). }\end{array}$ & $\begin{array}{l}\text { Events (Sequences): } \\
\text { Actions (Main object) } \\
\text { Happenings (Scenes) } \\
\text { Existants: } \\
\text { Characters } \\
\text { - Identity } \\
\text { - Interests } \\
\text { Settings } \\
\text { - Support object } \\
\text { (foreground, background) } \\
\text { - Accompanying object } \\
\text { Wimba } \\
\text { Sub Imaji } \\
\text { Imaji } \\
\text { Isi Wimba } \\
\text { Atmosphere } \\
\text { Navarasa }\end{array}$ \\
\hline
\end{tabular}


body movements: sub-imagi (the smallest element of an image), isi wimba (object drawn or described); characters (Identity and Interests), actions and attitudes. We carefully and systematically record what we see on the main character's body, from the head, neck, hands, body and feet, so we will know the gestures in detail. (3) Third stage, is the stage to find a significant relationship between the actions and behavior of the main character with elements: happening and events, atmosphere, settings (accompanying object, support object: foreground and background). The goal is to ensure the shape and quality of the gestures in the main character, especially in terms of character and attitude. (4) Fourth stage, the main indicator of the aesthetic expression of navarasa through the visual gestures of Karmawibhangga reliefs is to evoke emotions or feelings for those who see it, thus at this stage we can identify the meaning of the main character's gestures comprehensively, such as: standard patterns of HinduBuddhist iconographic expressions, distinctive gestures and expressions. unique in the daily interactions of the people depicted in the relief. The model of reading the main character's gestures with four stages of analysis, as illustrated in the following table 3 .

Table 3. Sheet of analysis four stage tabulation of the main character gestures

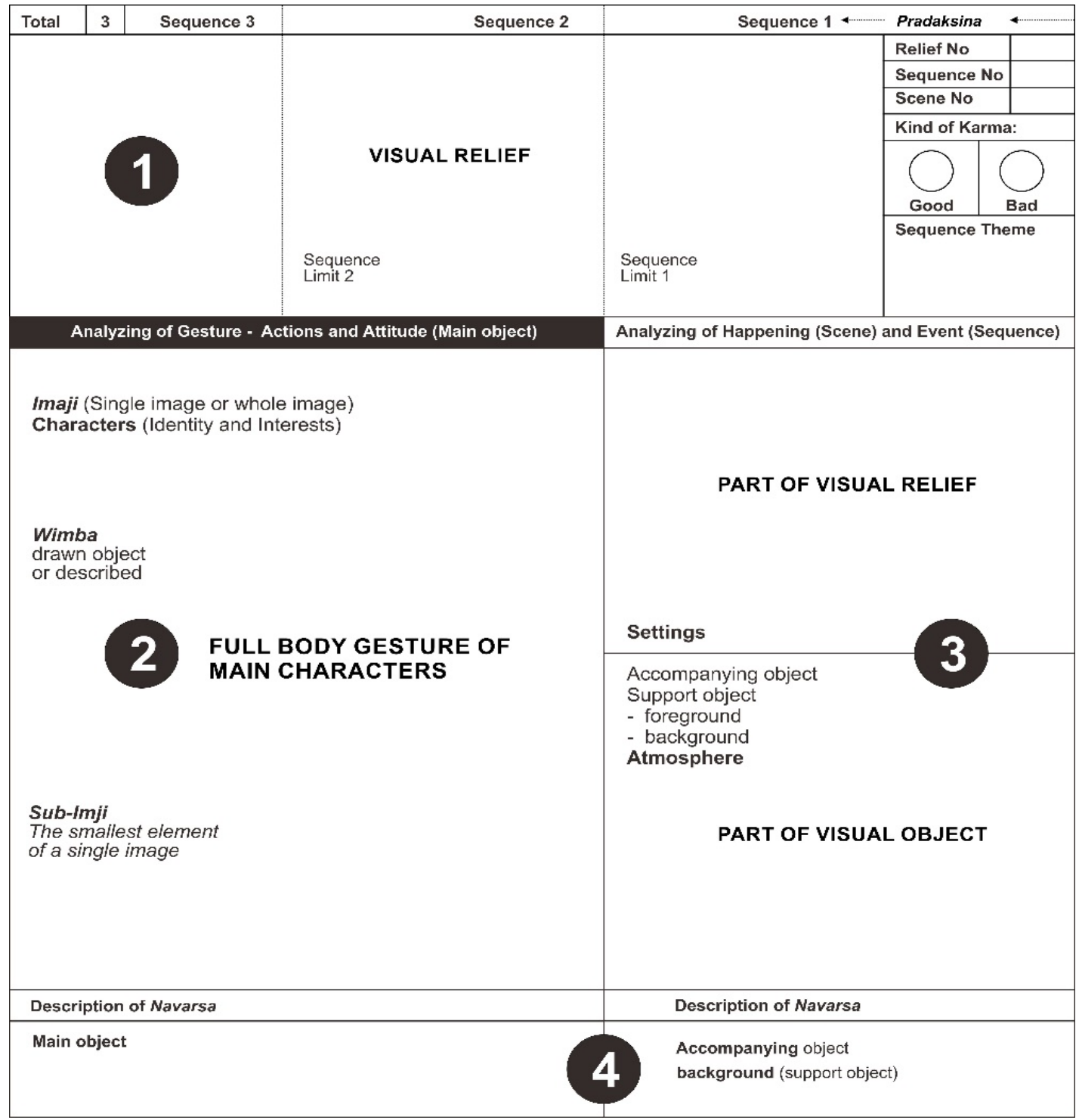




\subsection{Classification of Main Characters Gesture Using Navarasa Definition}

The following are forms of relief gestures that show the aesthetic concept of nawarasa as a manifestation of passion and desire (rasa), as shown in the example discussion in the following figure 2 .

In the navarasa perspective, the good and bad of human feelings and thoughts are built by external and internal factors and their manifestations are expressed through the expression of "taste" in human gestures.
External factors are social relationships and interactions in the form of behaviour and social actions (karma) that bring about cause and effect. Then the internal factor is a place to process, ponder, and decide what to do to respond to social interactions that will be experienced. A person's character, actions, and attitudes will be seen from body movements as a manifestation of thoughts and feelings. In navarasa there are nine good and bad feelings which are also depicted in the Karmawibhangga reliefs, various conditions and certain social situations in the impression of a good or bad social atmosphere.

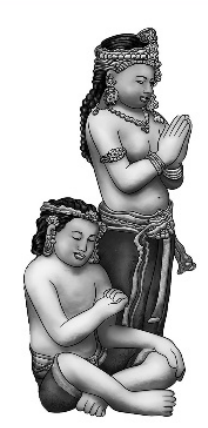

Adbhuta Rasa (The marvelous)

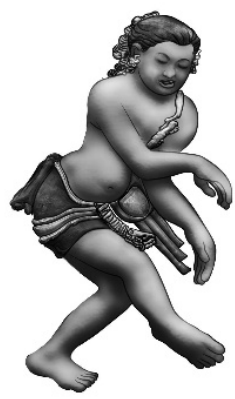

Hasya Rasa (The comic)

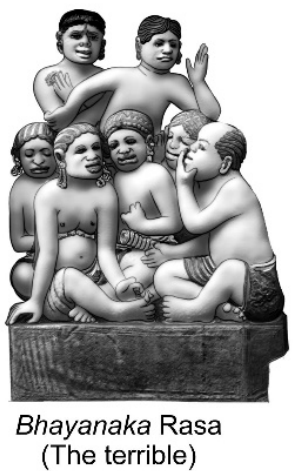

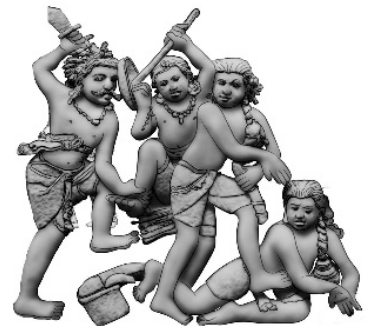

Vira Rasa (Heroism)
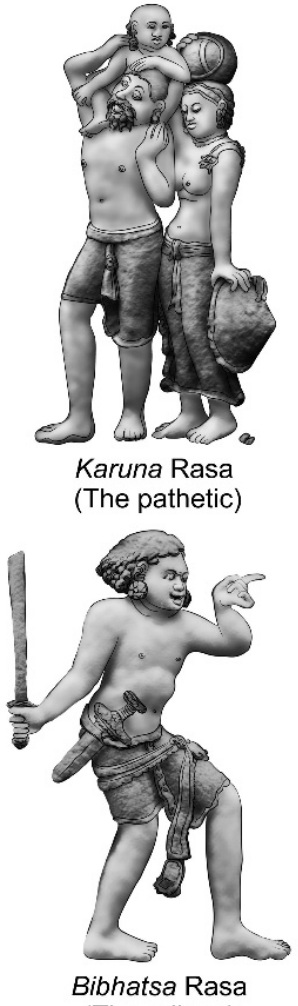

(The odious)

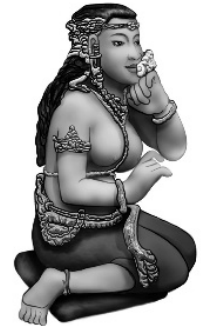

Srngara Rasa (The erotic)
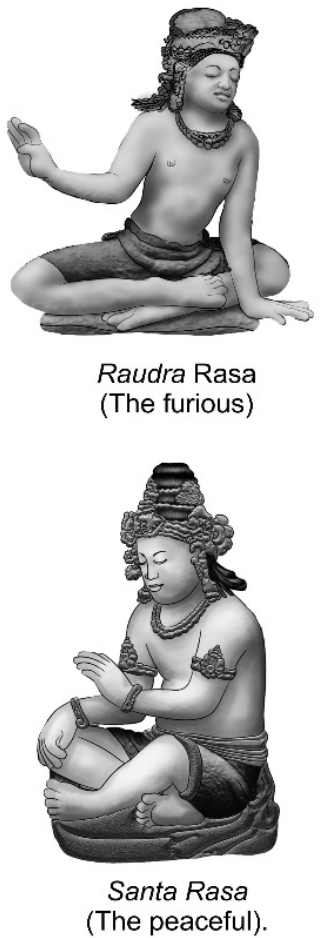

Figure 2. Classification of the main characters gestures using navarasa definition 


\subsection{The Main Characters Gestures in A Distinctive and Unique Relief}

By observing and classifying the main characters based on gestures that represent standard patterns of Hindu-Buddhist iconographic expressions such as yoga and mudra, we can see the differences in the gestures in the reliefs. Thus, a gesture that is not part of the standard mentioned above is a distinctive and unique gesture as a feature of ancient Javanese gestures, shown in figure 3. It can be seen that Figure (3a) above is a sitting pattern and hand position based on the Hindu-Buddhist style. Furthermore, in the Figure (3f) the bottom part shows the characteristics of sitting style and free hands and not bound by standard rules.

The natural, unique and distinctive gestures are depicted starting from the dancing gesture Figure (4a) to the lowest ascetic gesture Figure (4f). The depiction of gestures in the Karmawibhangga reliefs tells more about everyday life with various different social stratifications, in figure 4.

\subsection{An Example Reading the Main Characters Gestures}

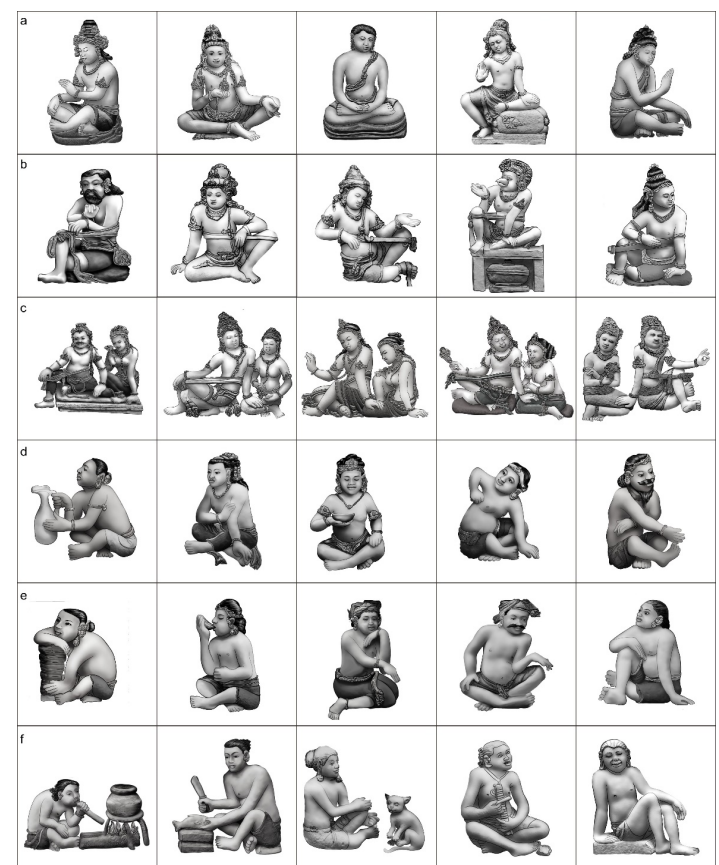

Figure 3. The main characters gestures in a distinctive and unique relief
As discussed in the methods section presented above, there are four stages of analyzing the reading of the main characters in the relief, as shown in the relief analysis example No. 021, in figure 5 .

Reading the main character's gestures Karmawibhangga Reliefs No. 022, as follows: (1) first stage: observe all the reliefs and determine the number of sequences and determine the main character. Look at the entire relief carefully, starting from the left to the right. There is a limit to the story sequence with a tree as sign, meaning that the relief has two sequences. There is a main character with a figure depicted throughout the body, the position of the body at the highest level. (2) Second stage: reading wimba and isi wimba, characters, actions, happenings on the main character's gestures: physical form and motion (head, hands, body, and feet), attributes of clothing worn and attitude towards the surrounding environment. Head, facing down right, looking at her baby lovingly; body, the position of the body slightly rotates and tilts to the right; hands, the position of the left hand holding the weight, right hand holding a cloth; foot, cross-legged position, right leg folded up and left leg folded to the side. Head with a crown, sitting position with right leg bent up and left leg bent to the side then wrapped in a cloth wrapped around the back to the knee, perfect sitting position.

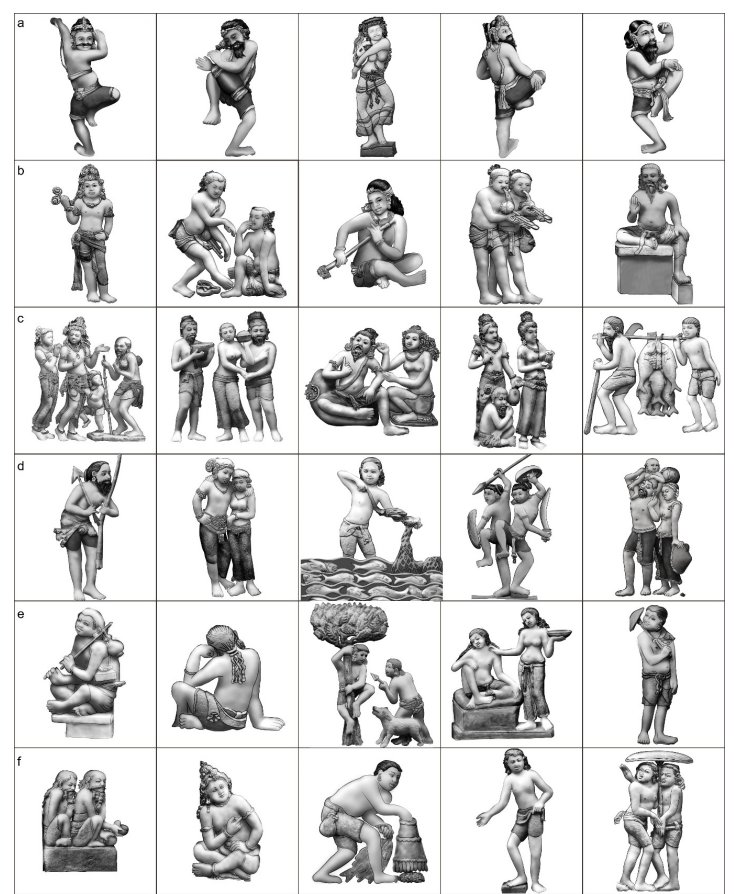

Figure 4. The main characters gestures in everyday life 


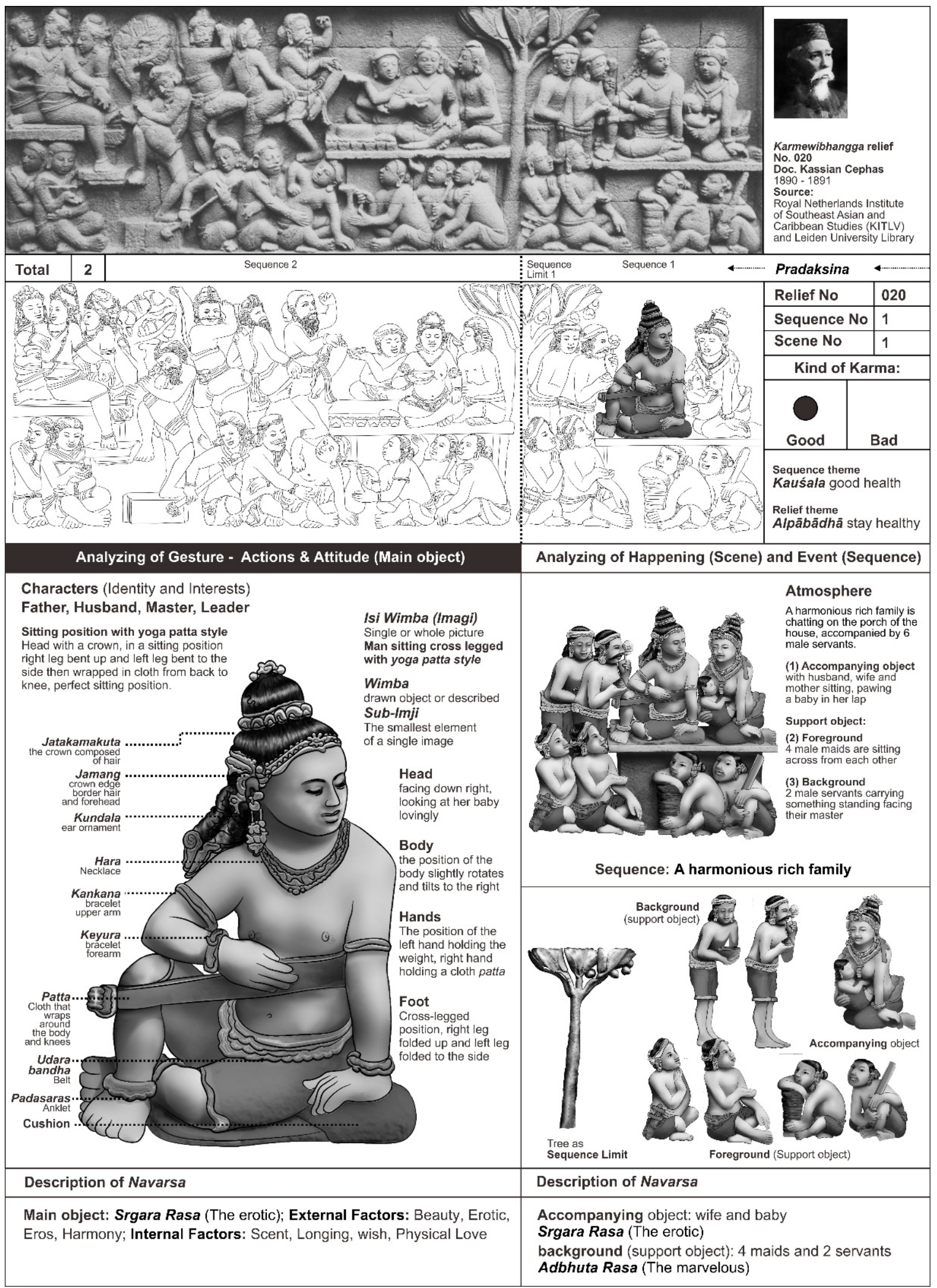

Figure 5. The main characters gestures in everyday life 
(3) Third stage: reading the main gestures in relation to the surrounding environment, atmosphere and settings (accompanying object, support object: foreground, background). The atmosphere in this sequence is "A harmonious rich family is chatting on the porch of the house, with six male servants". The activities are around outside the house because there is a tree and the family is sitting on the couch, possibly the veranda, and a tree as sequence limit, The settings in the sequence are: accompanying object (wife and mother sitting, pawing a baby in her lap); Support object: foreground (four male maids are sitting across from each other), background (two male servants carrying something standing facing their master). (4) Third stage: identify the meaning gestures comprehensively with navarasa aesthetics: main character, accompanying object, support object. Main object and accompanying object: Srgara Rasa (The erotic), External Factors (beauty, erotic, eros, harmony); Internal Factors (scent, longing, wish, physical love). Support object (four maids and two servants), Adbhuta Rasa (The marvelous), external Factors (beautiful, amazing, patience, strength), internal factors (fascinated, surprised, amazed, guessing).

The finishing stage of reading is to complete the main gesture by: Identity, attributes and habits (cultural code) on the main character. In the main character there is a code of culture, clothing and Adornments, including: jatakamakuta (the crown composed of hair), jamang (crown edge border hair and forehead), kundala (ear ornament) hara (necklace), kankana (bracelet upper arm). Keyura (bracelet forearm), patta (cloth that wraps around the body and knees) udarabandha (belt), padasaras (anklet) [13].

Complementary aspects, to interpret the gestures that have been read, in closing the process of reading the main character's visual gestures on the Karmawibhangga relief. After knowing the overall attitude and gestures of the main character, such as: wimba and isi wimba, events (actions and happenings) and existents (characters and settings), everything has been discussed. However, in the aspect of identity, naming and terms, as well as attributes and habits (cultural code), adequate supporting literature data is needed, such as various clothes and jewelry worn, yoga patta sitting style and mudra hand style often depicted in the main character of the Karmawibhangga relief. In reading stories, especially in reading the main characters, collaboration of the disciplines that intersect with them is needed. Thus, the reading of the main character's gestures becomes comprehensive and can be justified.

\section{RESULT AND DISCUSSION}

The reading of the main characters in the Karmawibhangga relief is the first step for a visual narrative research: substance of the story, form of discourse, substance of the discourse, and actually reading the main character is only a study of about "form of the story". It is open for visual narrative researchers to conduct research on the storytelling reliefs of Karmawibhangga, especially on aspects of story substance, discourse form and discourse substance.

Most of the visitors to Borobudur World Heritage do not understand the relief story of Karmawibhangga, while the ability to read and interpret the heritage of visual relief stories, especially the main characters in the relief stories, is very useful for visitors to build quality experiences and knowledge. The visual narrative structure approach and visual language are a combination of methods for reading visual relief narratives that focus on story forms (events and existents) to identify and understand the main characters (characters and actions) in the narrative structure of the Karmawibhangga reliefs. On the other hand, locality values in visual forms and relief stories can be approached with classical aesthetic methods that are in accordance with Karmawibhangga reliefs. Although the relief works of Karmawibhangga are influenced by Hindu-Buddhist art, the influence of this art culture can be transformed by our ancestors into the unique and distinctive form of ancient Javanese storytelling reliefs.

By focusing on the main character's gestures, the 160 visual reliefs of Karmawibhangga story can become the center of attention of visitors as a source of useful knowledge and experience. Borobudur has 1460 reliefs, thus research on visual stories on Borobudur reliefs requires better attention by researchers, professionals and the government to build a more comprehensive and scientifically accountable knowledge of Borobudur relief stories.

\section{REFERENCES}

[1] Miksic John N., Historical Dictionary of Ancient Southeast Asia. USA: Scarecrow Press, Inc.; 2007 
[2] Miksic John N., Borobudur Golden Tales of The Buddhas. Periplus Editions (HK) Ltd; 1991

[3] Bloembergen Marieke, Eickhoff Martijn, The Politics of Heritage in Indonesia (A Cultural History). Cambridge: Cambridge University Press; 2020

[4] Gombrich, R., What the Buddha Thought. Equinox Publishing; 2009

[5] Munandar Agus Aris, Adegan dan Ajaran Hukum Karma pada Relief Karmawibhangga. Seri Terbitan Candi Borobudur - 4. Balai Konservasi Borobudur; 2012

[6] Kendon Adam, Gesture: Visible Action as Utterance. Cambridge: Cambridge University Press; 2004

[7] Chatman Seymour Benjamin, Publisher: Cornell University Press; 1980

[8] Tabrani Primadi, Visual Language. Bandung: ITB Publishing Co.; 1990

[9] Monier Williams, Buddhism in its Connexon with Brahmanism and Hinduism and in its contrast with Christianity. Publisher: John Murray,Albemarle Street;1889

[10] Thampi G. B. Mohan, "Rasa” As Aesthetic Experience. Journal of Aesthetics and Art Criticism; 1965)

[11] Patton Laurie L., The Indo-Aryan Controversy: Evidence, History, and Politics. London: Routledge/Taylor Francis Press; 2005

[12] Sharma Nirmala, Aesthetic Pleasure: Representation of Rasas on the Hidden Base of the Borobudur. Uncovering the Meaning of the Hidden Base of Candi Borobudur. Indonesia: The National Research and Development Centre of Archaeology; 2008

[13] Ramachandra Rao, S. K., Pratima-Kosha Encyclopedia of Indian Iconography Vol I - IX, Bangalore - India: Kalpatharu Research Academy Publication; 1992 